\title{
MASTER
}

\section{Preliminary Thermal Expansion Screening Data for Tuffs}

Allen is. Lappin 
CONTENTS

$\underline{\text { Page }}$

Introduction $\quad 7$

Measurement Description 99

Data Collection Procedure 9

Precision and Accuracy of Measurements 11

$\begin{array}{ll}\text { Results } & 14\end{array}$

Expansion Behavior of Devitrified Welded Tufts 14

Expansion Behavior of Vitric Welded Tuffs and Obsidians 21

Expansion Behavior of Nonwelded TuffB 25

$\begin{array}{lr}\text { Conclusions and Discussion } & 29\end{array}$

References 33

APPENDIX -- Stratigraphic Positions and Sample Locations of 35 Anal yzed Samples

ILLUS TRATIONS

\section{Figure}

1 Generalized Map of DOE Nevada Test Site Showing Sample Locationa

2 Relative Linear Thermal Expansion of Eight Devitrified Welded Tuffs to $500^{\circ} \mathrm{C}$

3 Relacive Linear Thermal Expansion of Samples Ue25A*1-186 and Ue25A $\$ 1-2494$, Bath Devitrified Welded Tuff: 


\section{ILLUSTRATIONS (; ant)}

\section{Figure}

4 Relative Linear Thernal Exponsion of Two obsidians and Sample vi2jA*1-1:90\%.

5 Relative Linear Thermal Expansioll of Six Nonwelded Tuffs to $500^{\circ} \mathrm{C}$

6 Heating-Rate Dependence of Relative Linear Thermal Expansion, Sample GTEv6"1-181

7 Linear Expansion Coefficient to $200^{\circ} \mathrm{C}$ vs Final Pozosity of Analyzed Tutis and obsidians

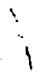

TABLES

Table

1 Ambient-Pressure Linear Thermal Expansion Coefficieits of Fused Si:ica as a Function of Temperature

2 Linear Thermal Expansion Coefficients of Devitrified Welded Tuffs

3 Available Bulk Properties Data

4 Linear Thermal Expansion of Devitrified Welded Tuff GTEv6:3-115

5 Linear Thermal Expansion Coefficients of Nonwelded Tuffs

6 Thermal, Themogravimetric, and Structural Data for the Most Common Zeolites in Silicic Tuffs 
PRELIMINARY EXPANSIDN SCREENING DATA FOR TUFFS

Introduction

The Nevada Operations Office (NVO) of the US Department of Energv (DOE) is studying the feasibility of nuclear-waste disposal in silicis: tuffe. General material properties data have been collecter as part of this atudy aimed at a preliminary assessment of modeling needs. This report discusaen data collected to date on the ambient-pressure thermal expansion of tuffs.

Silicic tuffs, which are fragmental deposits resulting from silicic volcanian, vary greatly in porosity, water content, and both prinary and secondary wineralogy. Tuff porosity may range from near 0 to greater than $50 \%^{1}$ with corresponding water contents. Tuffs differ widely in content of silicic glass, primary phenocryats, devitrification products (ailica polymorph plus feldspars and metal oxides), and secondary or authigenic minerals (especislly silica polyworphs, feldspars, zeolites, and clays).$^{2-4}$

For relioble thermomechanical modeling of waste disposal in tuffs, it will be necesury to understand within well-defined 1 imit the sengitivity of theranl expaneion of tuff nase to at leat the following variables: meralogy, porosity, temperature, presure, and time (heating rate). As a firat step toward this gool, the objectives of this report are to

1. Report amblent-preaure acreening data collected on coherent saples frow a broad range of tuffe

2. Hake prelininary asesenent of the censitivity of expansion to porosity and aineralogy 
3. Report initial measurements of the rate-depentent expansion of welded and nonwelded tuffB

4. Indicate special areas of intetest or concern for examination and evaluation in iurure studies.

For this report, the ambient-pressure thermal expansion of core samples of 24 different tuffs and 2 obsidians was qeasured--a total of more than 100 separate runs. Tuffo were taken from localities on the DOE Nevada Test site (NTS) as shown in Figure 1:

1. Hole Ue25Ali on the flanks of Yucca Mountain at the western edge of NTS

2. Well J-13 near the western edge of Jackass Flats

3. From within the G-tunnel complex beneath Rainier Yesa.

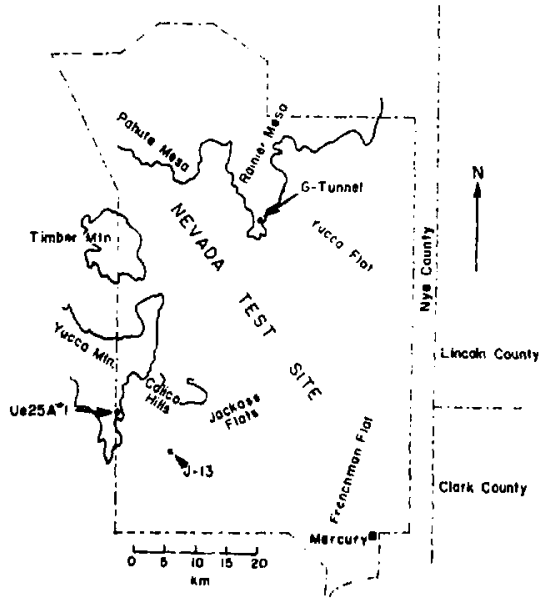

Figure 1. Generalized Map of DOE Nevada Teat site Showing Sample Location: 
Sample locations and stratigraphic positions of all analyzed tuffs are given in the Appendix. One obsidian is fron the Jemez Mountains of New Mexico and the other from an unknown locality.

\author{
Measurement Description
}

\title{
Data Collection Procedure
}

Measurement of linear thermal-expansion coefficients included in this report were made at arbient pressure on a Theta, Inc., Model "Dilatronic 9" dilatometer. This is a two-pushrod apparatus in wi:h parallel horizontal cods of fuged silica, $1 \mathrm{~cm}$ apart, are used. One rod contacts a fused silica standard the other contacts the sample being analyzed. The pushrods, which extend out of the clamshel? furnace used for heating the sample and standard, are connected to twc I inear dis" placement transducers. The sample is ground equal ii Jength to the silica standard $\pm 0.18 \mathrm{~mm}$. Nominal sample length is $2.54 \mathrm{~cm}$; shorter samples can be anslyzed since available standards range from 1.27 to $2.34 \mathrm{~cm}$. The heating rate of the furnace is programmable to rates of between $0.5^{\circ}$ and $10^{\circ} \mathrm{C} / \mathrm{min}$. Because the system i. not actively cooled, cooling rates are limited (especially at lower temperature) by the rate of heat loss from the furnece and omple/standard/pushrod assembly. Sample temperature is measured by a Chromel-Alumel thermocouple placed at the lengthwise midpoint of the anple and halfwy between the sample and silisa standard. Evtimated maximum error of the sample temperature measurement is $\div 5^{\circ} \mathrm{C}$; errors at slow heating rated are probably wuch salller.

Output during measurewent consists of a digital display of weasured uaple temperature and continuous graph of the change in saple length 4. a function of temperature $\left({ }^{\circ} \mathrm{C}\right)$ relative to the net change in length of the fused silica atandard to the sme temperature. Plotted and digital readout temperature are crosechecked periodically during runs and agree to within $5^{\circ} \mathrm{C}$. It is the chart record thet is preserved and from which expention coefficiente ere calculated. 
Samples used in these measurements are, when possible, taken from core material that was protected by wax and wrapped as soon as possibie after removal from the ground. Blanks are rough-cut to $5 \operatorname{sm} \times 5 \operatorname{mm} \times 3 \mathrm{~cm}$ on a water-cooled saw and, if necessary, stored in tap water before analysis. Just before measurement, samples are ground to the desired initial length and squared on a water-cooled lapulary wheel, using a machinist block for aligment. This process usually requires only 1 to 2 min per ample. Sample length before analysis is measured with a mechanical caliper (reasurements reproducible to $\pm 0.05 \mathrm{~mm}$ ) and recorded on the record chart; the ends of the sample are wiped dry and the sample is placed in the dilatometer for expansion measurement.

For this report, average linear expansion coefficients are calculated as follows :

1. Total changes of sample length relative to standard length ( $\mathrm{L} \mathrm{graph}$ ) are recorded over a given temperature interval.

2. The relative expansion coefficient of the sample between $T_{1}$ and $T_{2}\left(\alpha T_{1} T_{1}-T_{2}\right)$ is calsulated from

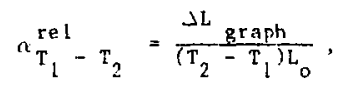

where $L_{0}$ is the initial sample length.

3. The final coefficient of the sample $\left({ }^{\mathrm{K}} \mathrm{F}_{\mathrm{T}}-\mathrm{T}_{2}\right)$, corrected for expansion of the fused silica standard, is calculated from

$$
\alpha_{T_{1}-T_{2}}^{f i n}=\alpha_{T_{1}}^{r+1}-T_{2}+" T_{1}^{s i 1}-T_{2},
$$

where $\alpha_{T_{1}}^{i i}-T_{2}$ is the average linear thermal

expansion of fuaed silica over the range $T_{1}-T_{2}, 5$

Table I showe reprenentative values and al oo 
temperature intervals over which expansion is generally averaged.

\section{TABLE 1}

Arbient-Pressure Linear Thermal-Expansion Coefficients of Fused silica as a Function of Temperature

\begin{tabular}{cr}
$\alpha\left(10^{-60} \mathrm{c}^{-1}\right)$ & $\frac{\mathrm{T}\left({ }^{\circ} \mathrm{C}\right)}{20-100}$ \\
\hline 0.50 & $100-200$ \\
0.60 & $20-200$ \\
0.55 & $200-300$ \\
0.62 & \\
& $20-300$ \\
0.60 & $300-400$ \\
0.57 & $400-500$ \\
0.51 & $20-500$ \\
0.57 &
\end{tabular}

\section{Precision and Accuracy of Measurements}

Four obvious factors may affect the precision of the measurements reported here:

1. Recorded sample terperatures may be offected by thermal gradiente within the dilatometer apparatus and by uncertainties in reading the chart record. Although reported temperatures are generally felt to be good to $+5^{\circ} \mathrm{C}$, this may not be true at high heating rates $\left(5^{\circ}\right.$ to $10^{\circ} \mathrm{c} / \mathrm{min}$ ) because of the presence of thermal gradients within the sample.

2. The recorded initial sample length is nc:ompanied by a mall uncertainty, as discussed above.

3. Initial heating rates (i,e., at temperatures below $35^{\circ} \mathrm{C}$ ) are onethat uncertain because the sample temperature and initial furnace ramp temperature for heating are matched mechanically by adjusting the ramping temperature upwards until a minimal furnace output is required. This may result in over- or underheating for - thort tine, depending on the heating rate. Effects of this uncertainty are not evident unles the length of the teet ample changes because of dehydration near room temperature. 
4. Sample inhomogeneitieg may play a major tole in limiting the precision of measurements on fairly small samples, especially in rocks that contain xenoliths or pumice fragments of the same size scale as the samples being measured. In order to make a Iinited sest of sample inhomogeneity effects and general precision, triplicate meagurements were made at a constant: heating rate of $1^{\circ} \mathrm{C} / \mathrm{min}$ on two amples containing abundant xenoliths and inhomogeneities, GTEv5 4 ? - 15 (welded) and GTEv3\$1-35 (aonwelded). These neasurements indicate that measured expansion coefficiencs are precise to about $+1 \times 10^{-6}{ }^{\circ} \mathrm{C}^{-1}$, but do not include effects of inhomogeneities larger than the samples analyzed.

Two main factors may affect the accuracy and applicability of these data--accuracy of instrmental calibration and inherent limitations in the interpretation and use of ambient-pressure data collected on aterials that were under in-situ stress before removal to the surface. Calibration of the dilatometer used in making these measurements is checked by weekly measurement of the linear expansion of $99.99 \%$-pure Pt metal to $500^{\circ} \mathrm{C}$. Analysis of 18 such runs yields an average net linear strain and expansion coefficifnt to $500^{\circ} \mathrm{C}$ of $0.4580 \pm 0.0001$ and $9.543 \pm 0.003 \times 10^{-6 \circ} \mathrm{C}^{-1}$, compared with National Bureau of Standards (NBS) reference values of 0.4592 and $9.57 \times 10^{-6} \mathrm{C}^{-1}$, respecively. ${ }^{6}$ These resules indicate accuracy of machine calibration to within $0.3 \%$.

Thermal expanaion coefficients reported here are based on measurements of total changes in sample length and therefore include effects of reversible and irreversible mineralogic transformations, in addition to changes in rock fabric (i.e., the opening or closing of microcracks and/or pores). The mineralogic transformations of greatest interest involve dehydration of clays, hydrated silicic glass and/or zeolites, all of which are diatinctly pregure-dependent, and changeg in silica polymorph cryatal lography.

In general, two types of presure must be conoidered in extrapolating a mineral reaction to depth--the pressure upon the solid phases in a system $\left(P_{*}\right)$ and that effective in confining the fluid within a syatem $\left(P_{f}\right)$. 
This is especially true with dehydration reactions. Data reported here are collecteo unde: diditions of $P_{S}=0.1 \mathrm{MPa}$ and $P_{f}=0 \mathrm{MPa}$. At depth, a variety of conditions are possible at a general total stress level (S) from. $P_{S} \neq P_{f}=S$ to $P_{S}=S, P_{f}=0$. Relacive fluid and solid pressures anysher. near a repository at depth would depend upon the relationship between local fluid permeabilities, heating rates, and fluid-release path lengths. Therefore, based on measurenents made here, extrapolation of dehydration reactions to repository depth will rely upon assumption or calculation of relarive fluid and solid pressures at the depths of interest. This approach is being acrively pursued, but is beyond the scope of this report.

Cooper and Sinmons ${ }^{7}$ have shown that ambient-pressure thermal expansicn caefficients may be affected considerably by the presence of both preexisting microcracks and cracks generated by expansion mismatches of constituent grains during heating. Microcracks may be present at anbient temperature because of several factors. If the rock is quartz- or cristobalite-bearing and has cooled through the $\beta-\alpha$ transition temperatures for either of these phases, significant microctacking is almost certain to be fiesent at ambient temperature unlesg cooling was slow enough to allow ainealing. Microcracking may also result from removal of samples from in-situ to surface enviroments because of mismatched compressibilitieg of constituent grains.

Preexiating microcracks should lead to initial ambient-pressure expansion coefficients that are luwer than at high pressure, since part of the expansion of constituent grains can be taken up by expansion into existing microcracks, Generation of microcracks because of mismatched the mal expansion of constituent graing should lead to apparent expansion values that increase with temperature more rapidly than da the coefficients of the constituent grains. Wang and $B r a c e^{8}$ have recently show that effecta caused by the presence of ricrocracks can persist to confining pressures of up to $200 \mathrm{KPa}$, depending upon rock type and ample thermal history.

While the extrapolation of dehydration reactions to deptho it feasible and relatively traight forward (given knowledge of in-situ fluid preaoures), the effacts of microcracks are not. Thus the expansion 
measurements reported here must be considered only as qualicative and should not be applied quantitatively to repository depths. Quantitative laboratory evaluation of the thermal expansion of tuffs at depth will require the development of techniques to nake measurements at known fluid pressures and effective confining pressures. Full evaluation of the behavior of tuff masses upon heating can only be made by in-situ testing.

Resuits

Expansion Behavior of Devitrified Welded Tuffs

As mentioned above, a major inherent variable of silicic tuffs is porosity. Within ash-flow sheets, variable porosity results from differing degrees of compaction of the initial fragmental debris cloud and from secondary processes such as devitrification and alteration. In this report, it is assumed that the final sampie porosity rather than the initial degree of welding controls sample behavior. Rocks are therefore grouped according to theit final porosity (which is measureable) rather than by their initial degree of welding (which can only be estimated qualita$t$ ively). However, there is a general currelation between final porosity and degree of welding. Tutfs with a final porosicy of $25 \%$ or less are considered welded; those with a porosity of greater than $25 \%$ are considered nonwelded. All porosities in this report were measured or calculated after heating the sample to between $105^{\circ}$ and $110^{\circ} \mathrm{C}$.

From an engineering point of view, the most striking feature of the ambient-pressure thermal expansion of devitrified welded tulfs is the degree of uniformity of the results, regardluss of sample source, porosicy, and wineralogy. Figurm 2 shows banges in length of right samples of welded cuff relative to fused silica as a function of temperature to $500^{\circ} \mathrm{C}$. Table 2 summarizes rumerical data for these same samples, and Table 3 summarizes available material properties data for all samples. 
As Figure 2 and Table 2 indicate, an "average" devitrified welded tuff displays a gradually increasing expansion coefficient to at least $300^{\circ} \mathrm{C}$. Care mut be taken to consider this variability when using a constant $Q$ for mechanical modeling. Use of a constant $\alpha$ based on measurements to $500^{\circ} \mathrm{C}$ (or even $200^{\circ} \mathrm{C}$ ) tends to overestimate expansion and, henct, stresses and displacements at lower temperatures. The significance of moInearity in the behavior of an "average" welded tuff in thermonechanica: modeling depends upon the degree of accuracy required.

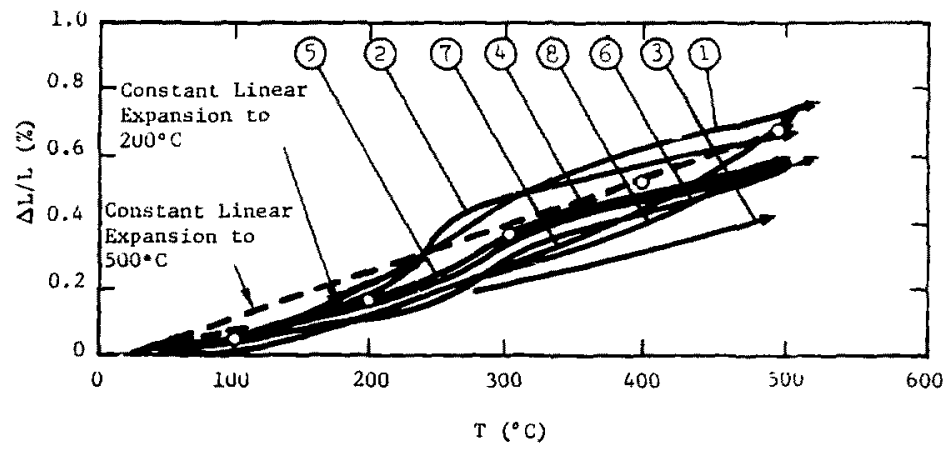

Porosity $(\%)$

1 Ue 25A\$1-166

7.5

2 Ue 2SA $1-186$

24.5

3 JA-13

4 CTEv6 $\$ 3-68$

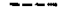

5 GTEv6 $\$ 3-80$

6 GTEV6\$3-115

14.6

7 Ue 25A $\$ 1-2494$

18.2

$83 A-29$

-...

- Average expansion of eight amples to indicated teaperature

Figure 2. Relacive linear Thermal Expansion of Eight Devitrified Welded Tuff = to $500^{\circ} \mathrm{C}$ (Heating Rate $* l^{\circ} \mathrm{C} / \mathrm{min}$ ) 
TABLE 2

Linear Thermal Expansion Coefficients of Devitrified Welded Tuffs $\left(a=10^{-6}{ }^{-1}\right.$ )

(Heating Rate $-1^{\circ} \mathrm{C} / \mathrm{min}$ )

Sanple Measurements

Ue25A*1-166
Ue25A:1-186
JA-13

Leasurements

GTEv6\$3-68

GTEv6\$3-80

GTEv6 3-115

Ue25A $1-2494$

2

2

2

2

2

2

3

JA-29

$\overline{\mathrm{x}}$ all

2

21

Temperature Interval $\left.\zeta^{\circ} \mathrm{C}\right)$

Temperacure Interval $\left({ }^{\circ} \mathrm{C}\right)$
amb-100 $100-200$ anb-200 $200-300$ amb-300 $\underline{300-400} \underline{400-500}$ amb-500

$\begin{array}{rrrrrrrr}9.0 & 15.9 & 12.5 & 24.4 & 17.2 & 18.6 & 11.5 & 16.0 \\ 6.8 & 13.6 & 10.6 & 29.9 & 17.5 & 9.4 & 9.8 & 14.2 \\ 5.8 & 8.8 & 7.5 & 8.9 & 7.9 & 10.6 & 13.5 & 9.7 \\ 8.0 & 12.6 & 10.6 & 19.1 & 13.8 & 1 . .1 & 13.0 & 13.9 \\ 7.8 & 10.1 & 9.1 & 16.9 & 11.9 & 14.9 & 13.2 & 12.8 \\ 6.7 & 8.4 & 7.8 & 15.7 & 10.6 & 16.6 & 15.4 & 12.9 \\ 4.0 & 10.3 & 7.5 & 14.0 & 9.9 & 18.5 & 25.8 & 15.1 \\ 6.8 & 10.6 & 8.9 & 11.6 & 9.9 & 15.6 & 20.5 & 13.3 \\ 6.9 & 11.3 & 9.3 & 17.6 & 12.3 & 15.0 & 15.3 & 13.5 \\ 1.5 & 2.6 & 1.8 & 6.9 & 3.5 & 3.4 & 5.3 & 1.9\end{array}$


TABLE 3

Available Bulk Properties Data*

Sample Bulk Grain

Location Density Density

Depth (ft) $\left(\mathrm{g} / \mathrm{cm}^{3}\right)\left(\mathrm{g}_{\mathrm{g}} / \mathrm{ca}^{3}\right)$ Calculated Neasured $\left(\% \mathrm{H}_{2} \mathrm{O}\right)$ Saturation

\begin{tabular}{|c|c|c|c|c|c|c|}
\hline \\
\hline \multicolumn{7}{|l|}{$\frac{\mathrm{Ue} 25 \mathrm{~A}+1}{166}$} \\
\hline 186 & 2.12 & 2.48 & 24.3 & - & 11.6 & -- \\
\hline 212 & 1.66 & 2.30 & 49.3 & - & 29.8 & -- \\
\hline $723^{* * *}$ & 2.33 & 2.56 & 12.9 & 12.8 & 4.0 & 0.80 \\
\hline 1290 & 2.33 & 2.40 & 3.7 & - & -- & -- \\
\hline 1490 & 1.99 & 2.42 & 28.1 & 29.1 & 12.2 & 0.86 \\
\hline 1544 & 1.95 & 2.43 & 34.0 & -- & 17.0 & - \\
\hline 1555 & 1.94 & 2.46 & 32.6 & 28.0 & 14.0 & 0.89 \\
\hline 1561 & 1.95 & 2.48 & 33.5 & 30.3 & 15.6 & 0.91 \\
\hline 1605 & 1.93 & 2.37 & 20.5 & 28.9 & 13.8 & 0.90 \\
\hline 1662 & 1.87 & 2.38 & 34.9 & 34.1 & 17,1 & 0.91 \\
\hline \multicolumn{7}{|l|}{1861} \\
\hline 1949 & 2.32 & 2.63 & 18.4 & 18.6 & 7.5 & 0.95 \\
\hline 1968 & 2.28 & 2.61 & 18.0 & 20.9 & 6.0 & 0.76 \\
\hline 1978 & 2.34 & 2.62 & 16.9 & 17.0 & 6.9 & 0.95 \\
\hline 1981 & 2.36 & 2.63 & 16.0 & -- & 7.0 & - \\
\hline 1985 & 2.36 & 2.62 & 14.5 & 15.8 & 5.1 & 0.83 \\
\hline 2402 & 2.28 & 2.61 & 19.2 & 20.7 & 3.5 & 0.89 \\
\hline 2423 & 2.23 & 2.62 & 23.6 & 23.7 & 10.3 & 0.98 \\
\hline 2432 & 2.33 & 2.64 & 18.2 & 18.1 & 7.5 & 0.96 \\
\hline 2453 & 2.23 & 2.61 & 20.3 & 24.2 & 7.1 & 0.78 \\
\hline 2492 & 2.30 & 2.60 & 17.7 & 20.8 & 6.9 & 0.90 \\
\hline 2494 & 2.34 & 2.64 & 18.2 & - & 7.8 & - \\
\hline \multicolumn{7}{|l|}{ S-Tunne I } \\
\hline $3 v 6 \neq 3-115$ & 2.36 & 2.58 & 14.6 & - & 6.4 & -- \\
\hline $8611-181$ & 1.69 & 2.20 & 42.8 & - & 25.2 & - \\
\hline $2 v 6 \$ 11-35$ & 1.96 & 2.50 & 35.6 & - & 18.1 & -- \\
\hline \multicolumn{7}{|l|}{ e.11 $J=13$} \\
\hline $3 A-6$ & 2.37 & 2.52 & 8.1 & -- & -- & - \\
\hline$J A-13$ & 2.41 & 2.64 & 12.3 & - & -- & -- \\
\hline$J A-22$ & 2.00 & 2.45 & 29.9 & -- & -- & -- \\
\hline$J A-29$ & 2.23 & 2.62 & 20.3 & -- & -- & - \\
\hline
\end{tabular}

*In one casee, data are for sample near one on which expanuion was mearured. **Entries including ample saturation are from References 9 and $10 ;$ all other are from unpublizhed data. 
In addition to the general nonlinearity in therwal expansion of devitrified welded tuffs, two digtinctive mineralogic effects are shown by sone samplea (Figure 3). Sample Ue25A\#1-186 frou the Tiva Canyon Member of the Paintbrush Tuff diaplays a marked nonlinearity between $220^{\circ}$ and $270^{\circ} \mathrm{C}$ on heating, and $230^{\circ}$ to $180^{\circ} \mathrm{C}$ on cooling because of the presince of cristobalite. Cristobalite is the major silica polyworph that results (along with alkali feldspars) frow simple devitrification of vitrified tuffe. 1 II It occurs mostly in shallower, younger units, such as the Tiva Canyon tuff, and is replaced by quartz in deeper, older tuffo such as the Bullfrog Nember of the Crater Flat Tuff from which sample Ue25AN1-2494 was taken. Since the phase relations of cristobalite are quite complex and could be of concern if any cristobalite-bearing tuff were heated above $\sim 200^{\circ} \mathrm{C}$ as a result of emplacement of nuclear waste, they are briefly discussed here.

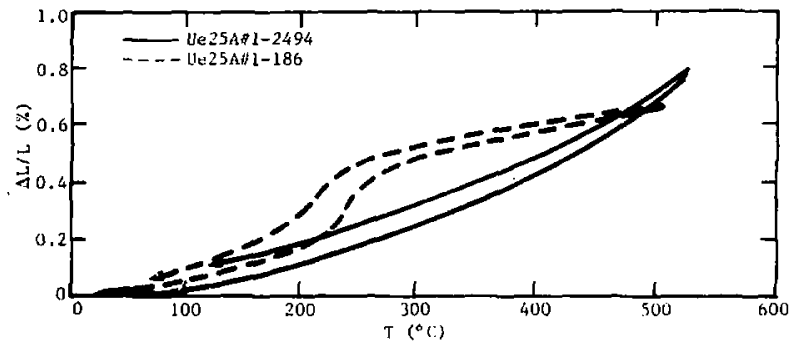

Figure 3. Relative Linear Thermal Expansion of Samples Ve25A\$1-186 and Ue25Af1-2494, Both Devitrified Welded Tuffs (Heating Rate = $1^{\circ} \mathrm{C} /$ min)

Upon heating, criatobalite inverta over some cemperature range from a low-temperature tetragonal form ( $\alpha$ cristobalite) to a cubic form ( $\beta$ cristobalite) atable at high temperatures. The most recent compilation of thermodynamic data for geologic materials 12 assigna a temperature of $250^{\circ} \mathrm{C}$ to the $\alpha-\beta$ transformation of cristobalite. However, as Sosman discusses, 13 the cemperature of the transformation and the volumetric increase accompanying it depend upon either the last (lowest) temperature at which the 
cristobalite was annealed ot the temperature of formation in unannealed samples. For example, cristobalites formed at temperatures of $850^{\circ}$ and $1600^{\circ} \mathrm{C}$ complerz inversion on heating at temperatures of $200^{\circ}$ and $775^{\circ} \mathrm{C}$, respectively. Inversion is defined as that point where the $X-r a y$ morphology changes from tetragonal to cubic symmetry, and occurs at the higutemperature site of the volunetric changes. Volmetric clualge during th? $\alpha-\beta$ cristobalite transformation ranges from 2 . $1 \%$ to $3.3 \%$, with samples formed at higher temperature $d i s p l a y i n g$ the $i$ arger volume changes. A final point of interest regarding the transformetion is that it shows a heating rate-independent hysteresis, with transfomation temperatire. during cooling $16^{\circ}$ to $40^{\circ} \mathrm{C}$ lower than on heating. 13 Samples equilituated at higher temperatures display a more marked hysteresis of inversion temperature. The cristobalite in Sample 186 completes inversion at about $260^{\circ} \mathrm{C}$ on heating, with an inversion hysteresis of $25^{\circ} \mathrm{C}$. Becarst of the presence of cristobalite, Sample 185 has a measured $\alpha_{L}$ between $230^{\circ}$ and $260^{\circ} \mathrm{C}$ of $57 \times 10^{-60} \mathrm{C}^{-1}$, compared with $13 \times 10^{-60} \mathrm{C}^{-1}$ for sample $? 494$, which lacks this phase.

Note that the presence or absence of cristobalite in welded tuff appears to have a major effect on thermal expansion on!y at temperatures greater than $200^{\circ} \mathrm{C}$. Because of this temperature limitation, the presence or absence of cristobalite would be expected tw have only a very 1 imited effect upon waste disposal except at higher power densities and temperetures.

Sample Ve25A1-2494, though it contains no detectable cristobalite, contains amall anount of biotite, wich characteriatically makes up as much as $2 \%$ of the Crater Flat Tuff. ${ }^{4}$ Mafic silicate phenocrysts in ashflow tuffa, especially hornblende and biotite, are frequently altered as a result of deuteric or vapor-phase alteration, much of wich is inherent to processes of degassing soon after emplacement. 14

Figure 3 show that Sample Ue 25A $1-2494$ contracts a very 81 ight mount $\left(60.037\right.$ by volue) between $50^{\circ}$ and $75^{\circ} \mathrm{C}$, after expanaion by approxiartely the sme amount between ambient tenperature and $50^{\circ} \mathrm{C}$. This contraction, with has been noted in 11 blanks of this sample that have been 
analyzed, is probably because of dehydracion of swall amounts of expandable clay present as a result of ilteration of the bio-ite. Prelininary thin-section exanination ot this sample indicatas a content of $1 \%$ to $2 \%$ by volume biotite with minimal alceration. If it is assumed that the observed contraction in this sample stens from the coliapse of the basal spacing of veraiculite and/or montmorillonite interlayers in the biotile from $15 \AA$ to $10 \AA$ upon dehydration, and that the biutite cantent of this rock is 17 by volume, then only $10 \%$ of the biotite need be altered to one of these expandable phases to arcomt for the observed beliavior.

This result suggests ciat small degrees of alteraticn of the biotitp in biotite-bearing welded tuffs can greatly affect the expansion of such tuffs near the boiling point of water, and could lead to smaller expansions and displacemencs than those expected in a sinilar tuff free of biotite. As an example, for a tuff with $2 \%$ biotite and a subboiling $\alpha_{L}$ of $10 \times 10^{-60} \mathrm{C}^{-1}$ to return to its initial volume after dehydration near $100^{\circ} \mathrm{C}$, the biotite needs to be altered $35 \%$ to $40_{\%}^{\text {tr }}$ to an expanding phase, the basal spacing of which collapsed from 15 \& to $10 \AA$ upon dehydration. Thus $0.8 \%$ by volume of expandable phase vould completely doninate the total expansion of this material to just above $100^{\circ} \mathrm{C}$. Increased in-situ fluid pressures would raise the boiling points of water, and hence the temperature at which clay contants becane critical. Very small variations in biatite content, or in degree of alteration, could thus significantly affect predictione of near-field stresscs and displacements resulting from waste emplacement in biotita-bearing tuffs. Thus, for applications at temperatures below about $200^{\circ} \mathrm{C}$, the single most critical mineralogic factor in predicting the matrix expansion of devitrified welded tuffs is a careful analyais and measurement of the degree and type of alteration of rafic silicate (and especially biotites) that those cuffs might contain. In addition, such predictions will require a good estimate of the fluid pressure actually present in any waste managenent application, since this controls the temperature at which the expandable phases dehydrate.

The possibility of anisotropic thermal expansion of walded tuff has been exained by multiple measurements on mutually perpendicular blanks; the resulta are guramarized in Tabie 4. Baged on these results, there 
appears to be no significant directional dependence of the ambientpressure lines expansion of devitrified welded tuffs.

TABLE 4

Linear Thermal Expanaion of Devitrified Velded Tufe GTEv6\$3-115

$\left(\alpha_{1}\right.$ in $\left.10^{-6 *} \mathrm{C}^{-2}\right)$ (Heating Rate $=1^{\circ} \mathrm{C} / \mathrm{min}$ )

amb-100 100-200 200-300 ant-300 300-400 400-500 anb-500

Perpendicular to Bedding

$\begin{array}{crrrrrrr}\text { Rug } & & & & & & \\ 1 & 6.9 & 8.6 & 17.6 & 11.4 & 17.6 & 15.5 & 13.6 \\ 2 & 6.3 & 8.6 & 16.6 & 10.4 & 16.6 & 15.5 & 12.6 \\ 3 & 5.6 & 8.1 & 15.1 & 9.9 & 17.1 & 14.0 & 12.3 \\ x & 6.3 & 8.4 & 16.1 & 10.6 & 17.1 & 15.0 & 12.8 \\ 1 & 0.7 & 0.3 & 1.3 & 0.8 & 0.5 & 0.9 & 0.7\end{array}$

Perallel to Bedding

$\begin{array}{crrrrrrr}\text { Run } & & & & & & & \\ 1 & 7.0 & 8.6 & 15.6 & 10.6 & 16.6 & 15.5 & 13.0 \\ 2 & 7.8 & 8.6 & 15.6 & 10.9 & 15.6 & 17.5 & 13.7 \\ 3 & 6.8 & 8.1 & 14.6 & 10.1 & 16.1 & 14.5 & 12.3 \\ x & 7.2 & 8.4 & 15.3 & 10.5 & 10.1 & 15.8 & 13.0 \\ 1 & 0.5 & 0.3 & 0.6 & 0.4 & 0.5 & 1.5 & 0.7\end{array}$

Expansion Behavior of Vitric Welded Tuffs and Obsidians

Measurements indicate that expansion of devitrified melded tuffs is fairly predictable and uniform, though greatly affected by the presence or absence of expandable clay and cristobalite. Limited results on vitric welded cuffs and obsidians indicate a more complex, less uniform behavior and suggest that the presence or abence of hydrated silicic glasses may be a major parameter to be considered in tuffs heated above the boiling point of water, just as is the presence or absence of expandable clays. Although any nonwelded tuffs examed as part of this study contain silicic glass, only the vitric welded tuffs and obsidians are considered in this section. A few of these are almost entirely glassy and offer some underatanding of the behavior of natural ailicic glasa itself. 
The silicic glasg in fresh, unaltered tuffs usually contains only a few tenths of a percent water, which is entrapped in the melt at high temperature and actually forms part of the silicate network within the glass. 15 Driving off such water at relitively high temperatures should cause the glass to contract, since water is an integral part of the melt structure and has a positive partial molar volume. ${ }^{16}$ silicic glasses, especially those in older tuffs, are often additionally hydrated by interaction with groundwater at deuteric or ambient temperatures. Total water contents of up to $7 \%$ by weight are not uncomon. ${ }^{3} 17$

The volumetric effects of the addition of this water at low temperature are not well undergtood. For example, Hoover ${ }^{3}$ argues that hydration occurs at constant glass volume, with the addition of water compensated for by leaching of cations, expecially Na. However, there is considerable scatter in the data he uses to support this argument. Ross and Smith ${ }^{15}$ also state that the volumetric changes upon hydration are small. The fact that cores of nonhydrated obsidian in perlite are separated from rims of hydrated obsidian by concentric cracks ${ }^{15}$ suggests, however, that some increase in glass yolume during hydration is likely at lower temperatures and, hence, this glass will contract if dehydrated.

Three samples have been examined as part of this study in an $7 t-$ tempt to unravel this uncertainty. Sanple Ue25A\#l-1290 from the basal vitrophyre of the Topopah Springs Member of the Paintbrush Tuff contains abundant black glass but is partially and irregularly altered to a very fine-grained, orange alteration product. The detailed nature of this product is still unclear, but it contains both glass and a zeolite (heulandite). The character of this unit in Hole Ue $25 A+1$ is very similar to it: appearance in Well, $1-13$, some $6 \mathrm{mi}$ distant. 18 two samples of obsidian were also studied as examples of less-altered material.

Therwogravimetric analyses of the two obgidians and of both the mostand leat-altered parts of Ue25A $\$ 1-1290$ were run on a atandard apparatus (DuPont Model 990) to examine volatile evolution behavior. The two obsidiand either contain no water or water below detectable levels. Both 
portions of Sample Ue 2SA $1-1290$, however, contain abundant water. The relatively ungltered portion of this sample retains about $4 \%$ by whigh of water after powdering for analysis. This is evolved discontinuously, since moat water ( $3 \%$ by weight) is released above $200^{\circ} \mathrm{C}$ (Figure 4). This ample thus appears to have been hydrated predoninately at relatively high cemperatures, probably by deuteric action. The more altered portion of Sample 1290 contains $10 z$ by weight of water, wich is evolved continuously to $400^{\circ} \mathrm{C}$; almost half of it is driven off by $100^{\circ} \mathrm{C}$. This type of water evolution is consistent with the presence of heulandite or clinoptilolite in this ample. Figure 4 also shows thermal expansion results for the same samples.

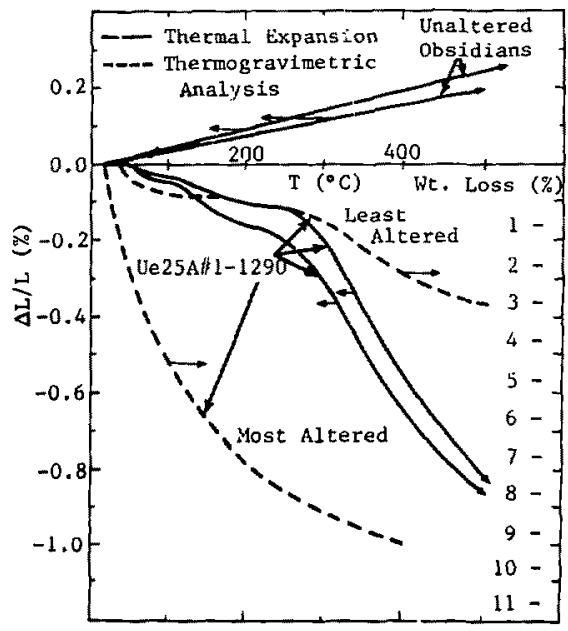

Figure 4. Relative Linear Thermal Expansion of Tho Obsidians and Suple Ue25A11-1290. (Also show are thermogravinetric resul to for Sample 1290 ; heating rate for expansion $1^{\circ} \mathrm{C} / \mathrm{min}$, for $\mathrm{TGA}-2^{\circ} \mathrm{C} / \mathrm{min}$ )

Theral expansion of the unaltered obsidians, assumed here to be equivalent to the behavior of nonhydrated or alightly hydrated ailicic glasa, 
is markedly different from the behavior of crystalline tuffs. Both obsidians show atrictly linear behavior with temperature as opposed to the general increase in $\alpha_{L}$ with $T$ shown by the crystaltine tuffs. The obsidians display no hysteresis upon cooling, again in contrast with the devitrified tuffs (Figure 3). The diatinction between the behavior of obsidian and of devitrified tuff is consistent with the interpretation that at least part of the increase in $\alpha_{L}$ with $T$ in crystalline rock results from microcracking caused by the mismatch of individual grains. ${ }^{7}$ The average $\alpha_{\mathrm{L}}$ to $500^{\circ} \mathrm{C}$ for the two obsidians analyzed is $5.0 \times 10^{-6}{ }^{\circ} \mathrm{C}^{-1}$, as opposed to 13.5 $\times 10^{-6}{ }^{\circ} \mathrm{C}^{-1}$ for analyzed devitrified welded tuffs.

Correlation of thermogravimetric and expansion results for Sample 1290 suggests that dehydration of natural glasses, especially at cemperature above $300^{\circ} \mathrm{C}$, measurably decreases glass volume. Figure 4 shows' only minor contraction of Sample 1290 below $150^{\circ} \mathrm{C}$, by which time the altered portion of this sample (which makes up some $10 \%$ by volume of the rock) has evolved $2 / 3$ of its water. The major increase in contraction rate of Sample 1290 correlates well with increased water evolutior frol. ve leastaltered part of this sample. Titis is indicated by the fact that the major inflection in the thermogravimetric data for this portion and the major increase in contraction rate for the sample as a whole both occur near $300^{\circ} \mathrm{C}$. The ample atill needs to be studied in detail to determine the dehydration/expansion response of the separate phases within the most altered portion.

From these data, it is tentatively concluded that almost all hydration of natural silicic glases results in at leat some increase in glass voluse; dehydration of such glasses should lead to contraction with hysteresis on cooling, as seen in Sample 1290. Water evolution from such glasses is highly variable, but becomes increasingly continuous and shifts to lower temperatures as the total water content increases. Thus the evolution of water at temperatures near $300^{\circ} \mathrm{C}$ appears to be associated with major contraction. It has not yet been posible to measure the effects of water evolution near $100^{\circ} \mathrm{C}$, although results suggest that removal of this more poorly retained water also lead to limited contraction. Certainly, dispoes of nuclear wates in a situation in which glass-bearing tuffs 
reach temperatures above the boiling point would be advised only if the time-temperatura-fluid pressure-volume relations of hydrated silicic glasses were much better undergtood that at present.

\section{Expangion Behavior of Nonwelded Tuffs}

As emphasized by the results show in Figure 2, expansion of welded tuffs appears to be independent of porosity. The extreme variability of expansion results for nonwelded tuffs, discussed below, requires consideration of possible porosity effects. If it is assuned that no cracks develop during expansion of an aggregate (i.e., that the individual grains are tightly bound to each other and that there are no shear stresses), the linear expansion of the aggregate can be approximated by ${ }^{19}$

$$
\alpha_{t}=\frac{\alpha_{1} X_{1} s_{1} / \rho_{1}+\alpha_{2} K_{2} F_{2} / \rho_{2} \cdots}{R_{1} F_{1} / \rho_{1}+K_{2} F_{2} / \rho_{2} \cdots}
$$

where

$$
\begin{aligned}
& \alpha_{r}=\text { expansion coefficient of the aggregate } \\
& \alpha_{i}=\text { expansion coefficients of the } i^{\text {th }} \text { phase } \\
& k_{i}=\text { bulk modulus of the } i^{\text {th }} \text { phase } \\
& F_{i}=\text { weight fraction of the } i^{\text {th }} \text { phase } \\
& \rho_{i}=\text { density of the } i^{\text {th }} \text { phase }
\end{aligned}
$$

Air-filled or unsaturated porosity can be simply treated as another phase in this formalism, a phase with a negligibly low-bulk modulus. Therefore, in theory, the presence of porosity should have no effect upon themal expansion so long as the assumptions given above are valid.

Results of measurements on nonwelded tuffs, shown graphically in Figure 5 and sumarized numerically in Table 5 , indicate general contraction between $100^{\circ}$ and $300^{\circ} \mathrm{C}$ for tuffa wich greater than $25 \%$ porosicy. All the nonwelded tuffs studied to date contain some clay mineral, apparently montmorillonite; many contain clay minerals, gilicic glass, and zeolite (clinoptilolite or heulandite). In general, highest-porosity amples cantract most. Although chi is inconsistent with intuition based on the sbove argument, ic is consistent with the generally observed increase in mineralogic complexity in the more parous samples. 


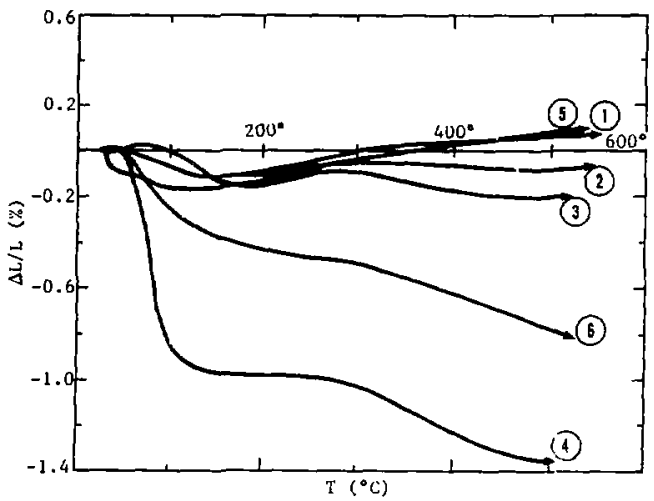

Porosity:

$\begin{array}{lll}1 & \text { Ue 2SA } \$ 1-1561 & 30 \\ 2 & \text { Ue 25A } \$ 1-1544 & 34 \\ 3 & \text { JA-22 } & 30 \\ 4 & \text { Ue25A } \$ 1-212 & 49 \\ 5 & \text { GTEV } \$ 11-35 & 36 \\ 6 & \text { GTEV } \# 3-181 & 43\end{array}$

Figure 5. Relative Linear Thermal Expansion of Six Nonwelded Tuffs to $500^{\circ} \mathrm{C}$ (Heating Rate $=1^{\circ} \mathrm{C} / \mathrm{min}$ )

TABLE S

Linear Tlerma] Expansion Coefficiencs oi lionwelded Tuffs (a $=10^{-6 \circ} \mathrm{c}^{-1}$ )

Sample

UE25A-21-2]2

CTEV6\$1-18!

( $\downarrow$ o of 4 meas urement $a$,

Sanple (B1)

GTEv $3+1]-35$

( $) \sigma$ of 3 measurements, Sample 35)

$J A-22$

Ue25A $1-1544$

Ue25At1-156!
Heating

Rate (oc/min)

amb-100 $100-200$

Tomperiture Interva $1\left({ }^{\circ} \mathrm{C}\right)$

$1 \mathrm{mb}-100 \quad 100-200$ 200-300 $10 \mathrm{mb}-300 \quad 300-400$ 400-500 anb-500

1

$$
-69.9
$$$$
-11.5
$$$$
-5.6
$$

$-25.2$

$-20.7$

$-i 1.1-21.2$

$-24.0-20.7$

$-5.5$

$-16.2$

$-10.3$

$-14.0-14.5$

$\begin{array}{rrrrrrr}1.5 & 1.2 & 0.6 & 0.8 & 0.3 & 0.7 & 0.6\end{array}$

$-20.5$

$+3.8$

$+10.1$

$-0.7$

$+5.6$

$+4.5$

$+1.7$

$$
1.11 .0
$$

$$
0.5
$$

0.1

0.5

0.5

0.3

$0.7 \quad-12.6$

$+4.6$

$-2.7$

$-4.7$

$-4.3$

$-3.4$

$-9.4 \quad-2.2$

$+6.3$

$-1.1$

$+0.8$

$-0$.

$-0.0$

1

$-9.1-0.7$

$+9.9$

$+1.0$

$+4.4$

$+3.2$

$+2.3$ 
The rough correlation of high porosity and mineralogic complexity evident from atudies to date appears to be related to tuff genesis. The predominance of 8 ilicic glass in both the highly pozous nonwelded tuffs and in the low-porosity basal vitrophyre of the Topopah Springs appears to be a regult of the facts that (1) glass in the conwelded tuffs was originaily emplaced at relatively low temperatures, either as ash-fall debris, or as cool (and hence nonwelded) rargins on an ash-flow sheet; and (2) the basal vitrophyre portion of an ash-flow sheet, though quite hot at the time of emplacement and hence very densely welded, is cooled quite rapid$1 y$, often before devitrification can occur. 1114 In addition, the very low porosity of the vitrophyre itself should limit the deuteric action that wight enhance devitrification. The apparent predominance of clay materials in the nonwelded tuffs also appears to be related to their original high porosity and glass content. In general, the normal alteration sequence of natural silicic glasses io hydration and leaching by interaction with groundwater or pore fluids, 320 followed by alteration of their rims to either zeolites or, more commonly, montmorillonite. 321 Thus, the widespread occurrence of clays and zeolites in the nonwelded rocks studied here appears to be directly related to their original glass contents and is not an isolated phenomenon. 14

Two series of tests were run to make a preliminary evaluation of the effects of differing heating rates on the themal expansion behavior of tuff:. Cyclic measurements of expansion of one welded tuff (GTEv6*3-115) at heating rates of frow $0.5^{\circ}$ to $10^{\circ} \mathrm{C} / \mathrm{min}$ indicated no statistically significant variations in expansion rate, either as a Eunction of initial heating rate or as a function of previous sample history. Measurements on a high-porosity nonwelded sample (GTEv6*1-181) support the interpretation thet expansion/contraction of nonwelded samples is a strong function of dehydration reactiona and, hence, of fluid presaure (Figure 6). The temperature at which the first major contraction begina on initial heating is consictently proportional to the heacing rate, as is the total sample contraction. After reheating, sample contraction is greater in more rapidy 
heated somples. These regults are further evidence of the potential complexities in waste-managent activities resulting in significant heating of nonwelded tuffa.

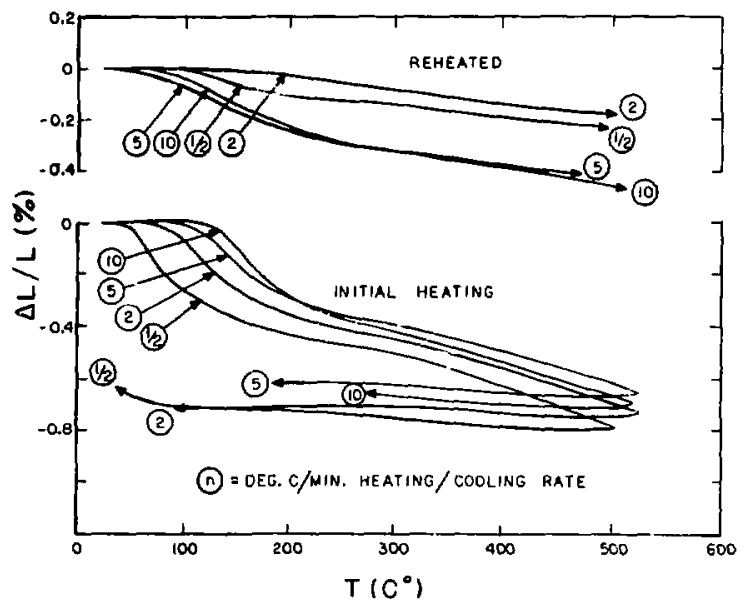

Figure 6. Heating Rate Dependence of Relative Linear Thermal Expansion, Sample GTEv6*1-181

Measurements to date on nonwelded tuffs indicate that at least tinree major factor need to be much better der:. 2 before their behavior at depth can be understuod. Porosity collapse, which appears not to be a factor in expansion of welded tuffa, may play a major role in in-situ reponse of nonwelded tuffs. Deternination of this effect is likely to be coaplicated by an additional correlation of increased mineralogical conplexity with increasing porosity. This correlation appears at preant to be related directly to the genesis of high-porosity tuffa. As shown by preliminary heting-rate experiments, the high-water content and mineralorical complexity of nonwelded tuffs result in their expansion behavior being dependent on fluid preseure. 
One entire class of minerals (zecites) that is quite widespread in silicic tuffs and related sediments ${ }^{3} 22$ has not been considered here. Some of the nonwelded samples studied contain appreciable zeolite, especially Ev6\$1-181, Ev3\$11-35, JA-22, and samples from near the 1500-ft level of be25Afl. The predoninant zeolite in these samples is elinoptilolite, Other zeolites reported at $\mathrm{Nrs}^{3}$ or in the $\mathrm{J}-13$ we11 18 include chabarite, analcime, mordenite, erionite, phillipsite, and heulandite. The extent of the distribution of zeolites other than clinoptilolite and analcime is minor. Table 6 , modified from Reference 23, sumarizes the available differential themal analysis, themogravimetric analysis, and structural stability data for these minerals.

As shown, the evolution of water from these zeolites, except for phillipsite and heulandite, is continuous and results in no structural changes, shrinkage, or instability to temperatures as high as $750^{\circ} \mathrm{C}$, at least on a short-cem sasis. It is therefore concluded that the major effect of variable zeolite contents in tuffe (except for phillipsite and heulandite) is to vary the water-evolution history and hence fluidpressure history in the heated area rather than to vary the expansion rem sponae directly. As shown by Sample Ve25A-1290, however, the presence of heulandite directly affects expansion. Note that the sbove conclusion also assumes that the zeolites have no significant effect on the elastic and mechanical properties of a given tuff.

Conclusions and Discussion

The primary goal of this report is to present preliminary data on the ambient-presaure thermal-expanaion behavior of a broad range of tuf $\mathrm{fs}_{\mathrm{s}}$. Figure 7 hows the general range of tuffe exained to date and indicates the everage linear expanaion coefficient to $200^{\circ} \mathrm{C}$ of all samples analyzed, as a function of final smple porosity. 
TABLE 6

The rmal, The znogravinetric, and structural Data for the tost Common zeolites in silicic Tuffs*

Type of Zeolite and Comments

\section{Clinoptilolite}

Analcine (najor, especially at depth)

\section{Mordenite, \\ not uncomaion \\ Erionite, minor \\ Heulandite traces; sose old literature reports clinoptilolite \\ as heulandite}

\section{Phillipsite, traces}

Chabazite, minor

Fiodified from Reforence 23
DTA

Endotherm, $125^{\circ}$ to $300^{\circ} \mathrm{C}$

Endo the rm, $200^{\circ}$ to $400^{\circ} \mathrm{C}$

Endothern, $25^{\circ}$ to $300^{\circ} \mathrm{C}$

Endotherm, $50^{\circ}$ to $400^{\circ} \mathrm{C}$

Endo the rm, $25^{\circ}$ to $300^{\circ} \mathrm{C}$; discrete at $350^{\circ} \mathrm{C}$

\section{Endotherms at $100^{\circ}$, $200^{\circ}, 300^{\circ} \mathrm{C}$}

Endo the rm, $25^{\circ}$ te $300^{\circ} \mathrm{C}$
TGA

\section{Continuous; $\Sigma 14 \%$ \\ Continuous veight loss to $400^{\circ} \mathrm{C} ; \Sigma 8.7 \%$ dehydration reversibie}

Continuows; $216 \%$

Continuous; $\Sigma 15 \%$

Scepwise weight loss, nea $100^{\circ}$ and $250^{\circ} \mathrm{C}$; $\sum 17 \%$

Stepwise weight loss, starting mear $130^{\circ} \mathrm{C}$ $\Sigma 18 \% 0300^{\circ} \mathrm{C}$

unucus: $\sum 23 \%$
Structural Stability

Stable to at least $750^{\circ} \mathrm{C}$

stable to $700^{\circ} \mathrm{C}$

Stable to at least $800^{\circ} \mathrm{C}$

Stable to at least $750^{\circ} \mathrm{C}$

Transforms to heulandite "B" near $250^{\circ} \mathrm{C}$; scructure collapses above $360^{\circ} \mathrm{C}$; some lattice contraction to $180^{\circ} \mathrm{C}$ the start of transformation

New structure forms at $160^{\circ}$ to $200^{\circ} \mathrm{C}$; stall change,

"metaphil lipsite"

Slable to at least $700^{\circ} \mathrm{C}$ 


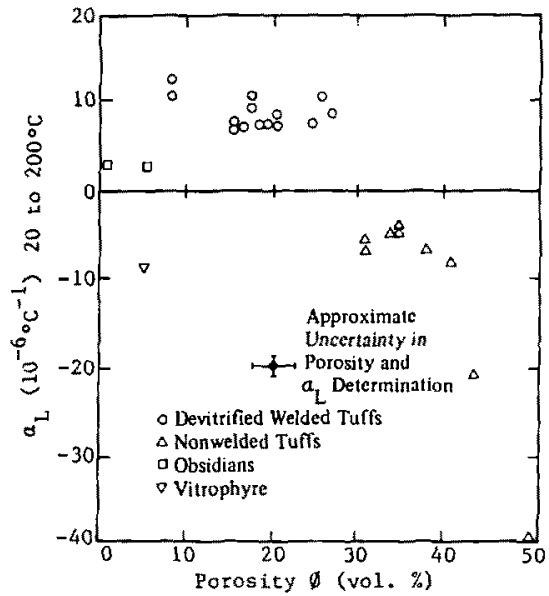

Figure 7. Linear Expansion Coefficient to $200^{\circ} \mathrm{C}$ vs

Final Porosity of Analyzed Tuffs and obsidians

Devitrified welded tuffs, analyzed samples of which have final porosities of between $8 \%$ anci $26 \%$, are fairly uniform in behavior to $200^{\circ} \mathrm{C}$; the $\alpha_{L}$ for all 14 such samples analyzer is $8.9 \pm 1.6 \times 10^{-60} \mathrm{C}^{-1}$. The expansion of these tuffs is apparently independent of heating rate and orientation and is messurably affected by two mireralogic factors: the presence of cristobalite in some saples, which reaults in markedly nonlinear expansion between $200^{\circ}$ to $300^{\circ} \mathrm{C}$; and posible partial alteration of the biatite in biotite-bearing tuffs to expandable clays (vermiculite and/or montmorillonitel. Although biotite contents of silicic tuffs are generally amall (i.e., less than 37), alceration of this phase could assily dominate expansion behavior near the boiling point of water.

Expanaion behavior of both high- and low-porosity tuffa that contain hydrated ailicic glass and/or expandable clays is largely dominaced near the boiling point by the dehydration and resultant contraction of these phsses. The apparent correlation of porosity and mineralogy in amples 
studied here appears to be genetically inherent in cuffs. Because of their structural atability, the most frequently reported zeolites appear not to have a measurable direct effect on the themal expansion of tuffs.

With the important exception of biotite-free devitrified welded tuffs, variations in tluid pressure affect the expansion behavior of silicic tuffs, since the two major reactions occurring below $200^{\circ} \mathrm{C}$ involve dehydration of a hydrated phase. The reliability of extrapolation of the results presented to repository depths will depend on: (1) a valid understanding of rate-dependent and fluid-pressure effects upon dehydration behavior of expandable clays and silicic glasses at realistic fluid pressures (these pressures are lower than those normally exmined in experimental petrology); and (2) a proper understanding of the effects of both micro- and macrofractures on the themal expansion of cuff masses, an undergtanding that $c$ an be gained only through in-situ tesing. However, based on the results presented here, the thermal expansio: uncertainties involved in wate management in silicic tuffs should be mi mized by using devitrified welded tuffs free of both appreciable bi re and cristobalite. 
1. R. L. Snith, Zones and Zonal Variations in Welded Ash Flows, USGS*, Prof. Paper 354-F (Washington: Government Printing office, 1960).

2. P. W. Lipnan, R. L. Christiansen, and J, T, D'Connor, A Compositionally Zoned Ash-Flow Sheet in Southern Nevada, usGS, Prof. Paper 524-E (Waskington: Government Printing office, 1966).

3. D. L. Hoover, "Genesis of Zeolites, Nevada Test Site," in E. B. Eckel, ed., Nevada Test Site, Geol. Soc. Am., Mem. 110, 1968, p 275.

4. E. M. Byers, Jr., W. 3. Carr, P. P. Orkild, W. D. Quinlivan, and K. A. Sargent, Volcanic Suites and Related Cauldrons of Timber MountainOasis Valley CaIdera Complex, Southern Neveda, USGS, Prof. Paper 919 (Washington: Goverment Printing office, 1976).

5. R. K. Rirby and T. A. Hahn, Certificate of Analysis, standard Reference Material 739 , Fused Silica, National Bureau of Standards, US Dept. of Commerce (Washington: Governent Printing office, May 12, 1971).

6. R. R. Kirby, National Bureau of Standards, US Dept. Of Commerce, Untitled meno to X. Bety, Labtronics, Box 566, 26 Valley Road, Port Washington, NY, October 1, 1971.

7. H. W. Cooper and G. Simmons, "The Effects of Cracks of Thermal Expansion of Rocks," Ear. Plan. Sci. Lett," 36, 1977, p 404.

8. T. F. Wong and W. F. Brace, "Meagurements of Thermal Expansion of Rocks at High Pressure (abs.)", EOS 58, 1977, p 1236.

9. N. B. C. Yelamanchili, H\&N Nevada Test Site, Meno to A. R. Lappin, Sandia Laboratories, "Physical Properties of Rock Cores From Drill Hole UE 25A:1," December 19, 1978.

10. N. B. C. Yelananchili, H\&N Nevada Test Site, Mero to A. R. Lappin, Sandia Laboratoriea, "Physical Properties of Rock Core Samples From UE 25A\#1 Drill Hole," April 5, 1979.

11. C. S. Ross and R. L. Soith, Ash-Flow Iuffs, Their Origin, Geologic Relations, and Identification, USGS, Prof. Paper 366 (Wauhington: Governaent Printing office, 1961).

12. R. A. Robie, B. S. Hemingway, and J, R. Fisher, Thermodynamic Properties of Mineral and Related Substances at $298.15 \mathrm{~K}$ and $1 \mathrm{Bar}$ (105 Paecle) Preseure and at Higher Teaperatures, USOS, Bull. 1452, (Weshingcon: Government Printing Office, 1978).

*us ceological survey 
13. R. B. Sosman, The Phaseg of Silica, (New Brunswick, NJ: Rutgers University Press, 1965).

14. R. L. Swith, "Ash Flows," Geo1. Soc. Am, Bu11, 71, 1960, P 795.

15. C. S. Ross and R. L. Smith, "Water and Other Volatiles in Volcanic Glasses," Am. Miner., 40, 1955, p 1071.

16. C. W. Burnham and N. F. Davis, "The Role of $\mathrm{H}_{2} \mathrm{O}$ in $\mathrm{Sil}$ icate Melts I, $P-V-T$ Relations in the Sygtem NaAl Si ${ }_{3} \mathrm{O}_{8}-\mathrm{H}_{2} \mathrm{O}$ to $10 \mathrm{KilObars}$ and $1000^{\circ} \mathrm{C}, "$ Am. Jour. Sci., 270, 1971, $\mathrm{p} 54^{\circ}$.

17. P. W. Lipman, Chemical Comparison of Glassy and Crygtalline Volcanic Rocks, USGS Bull. 1201-D (hashington: Goverment Printing Office, 1965).

18. G. H. Beiken and M. L. Bevier, Petrology of Tuff Units From the J-13 Drill Site, Jackass Flats, Nevada, Los Alamos Scientific Laboratory In formal Report LA-7563-MS, 1979.

19. W. P. Kingery, Introduction to Ceramics (New York: hh Wiley and Sons, 1967).

20. C. Colella, R. Aiello, and C. Procelli, "Hydration as is Early State in the Zeolitization of Natural Glass," in L. B. Sand ani F. A. Mumpton, eds., Natural Zeolites, Occurrence, Properties, Use (Elms ford, NY: Perganon Press, 1978).

21. L. V. Benson, Mass Transport in Vitric Tuffs of Rainier Mesa, Nye County, Nevada, US ERDA paper NVO-1253-10, 1976.

22. R. L, Hay and R. A. Sheppard, "Zeolites in Open Hydrologic Systems," F. A. Mupton, ed., Mineralogy and Geology of Natural Zeolites, Min. Soc. Am., Short Course Notes, $4,1977, \mathrm{p} 93$.

23. D. W. Breck, Zeolite Molecular Sieves (New York: John Wiley and Sons, 1974). 
APPENDIX

Stratigraphic Positions and Sample Locations of Analyzed Samples

Sample Location and Depth ( $f r)$

Hole Ue25A 1

166

186

212

1290

1544

1555

1561

1569

1861

1981

2365

2401

2427

2494

Wel1 J-13

JA -6

$3 A-13$

$3 A-22$

JA -29

G-Tunnel Conplex

Ev6*3-68

Ev6 $63-80$

Ev6\$3-115

Ev6\$11-35

INST 7-161

Ev6+1-181

\section{Stratigraphic Position}

Tiva Canyon Member, Paintbrush Tuff

Topopah Springs Member, Paintbrush TufE

TuEfs of Calico Hills

Prow Pass Member, Crater Flat Tuff

Bullfrog Nember, Crater Flat Tuff

Tiva Canyon Member, Paintbrush Tuff

Topopah Springs Member, Paintbrush Tuff

"Bedded Tuff," Paintbrush Tuff

Bull frog Member, Crater Flat Tuff

Grouse Canyon Member, Belted Range Tuff

Tunnel Bed 4, Local Unit

Tunnel Bed 5, Local Unit 